$7-31-2020$

\title{
Health education projects in Portuguese schools: A multicases study
}

Hugo Oliveira

Vilamoura International School, Portugal, hugo.oliveira@civ.pt

Jorge Bonito

Research Center in Education and Psychology (CIEP) and School of Social Sciences, Evora University, Portugal and Research Center for Didactics and Technology in the Training of Trainers (CIDTFF), Aveiro University, Portugal, jbonito@uevora.pt

Follow this and additional works at: https://scholarhub.ui.ac.id/ajce

Part of the Educational Assessment, Evaluation, and Research Commons, and the Health and Physical Education Commons

\section{Recommended Citation}

Oliveira, Hugo and Bonito, Jorge (2020). Health education projects in Portuguese schools: A multicases study. ASEAN Journal of Community Engagement, 4(1).

Available at: https://doi.org/10.7454/ajce.v4i1.1089

Creative Commons License

(c) (i) (?)

This work is licensed under a Creative Commons Attribution-Share Alike 4.0 License.

This Research Article is brought to you for free and open access by the Universitas Indonesia at ASEAN Journal of Community Engagement. It has been accepted for inclusion in ASEAN Journal of Community Engagement. 


\title{
Health education projects in Portuguese schools: A multicase
}

\author{
study \\ Hugo Oliveiraa, Jorge Bonito ${ }^{\mathrm{bc} *}$ \\ aVilamoura International School, Portugal \\ ${ }^{b}$ Research Center in Education and Psychology (CIEP) and School of Social Sciences, Evora University, \\ Portugal \\ cResearch Center for Didactics and Technology in the Training of Trainers (CIDTFF), Aveiro University, \\ Portugal
}

Received: May 31st, 2020 || Revised: June 26th 2020 || Accepted: July 26 ${ }^{\text {th }}, 2020$

\begin{abstract}
Health education projects (HEP) incorporate all the educational projects of the Portuguese elementary and secondary schools in order to respond to four key areas: mental health and violence prevention; food education and physical activity; addictive behaviors and dependencies; and affection and sexuality education. This study aimed at identifying the effects of HEP as they are perceived by teachers and students. A multicase study was developed in five schools in the municipality of Castelo Branco, Portugal. The sample consisted of a HEP coordinating teacher and one student from each case. The content analysis of each HEP was performed and semi-structured interviews were conducted with the participants. The analysis of the information showed that HEPs induce positive changes in the educational community lifestyle, and especially in students. Despite this positive view, targeted areas were diagnosed for optimization processes in each of the four dimensions of the HEPs being studied. This allowed the different projects to qualitatively improve their performance among the target audience. The investigations acknowledged the lack of instruments and methodologies able to record the behavioral changes developed within the scope of health education (HE) while simultaneously stimulating reflection on these behavioral changes and their causes.
\end{abstract}

Keywords: projects; health education; health promotion; evaluation; schools.

\section{Introduction}

Health Education (HE) programs in schools offer unique opportunities to establish and reinforce children's social skills through specific programs that work to prevent rather than cure problematic aspects of their health-related quality of life (Alfaro, 2017; Karasimopoulou, Derri \& Zervoudaki, 2012). Their primary objective is to noncoercively modify individual and collective behaviors and improve the community's health level through a set of educational practices (Morón, Pedrero \& Pérez, 2017). HE programs have a long tradition in school curricula but have generally focused on single causes of health problems, such as smoking, abuse of alcohol, and other psychoactive substances (Burgher, Rasmussen \& Rivett, 1999).

*Correspondence Author: jbonito@uevora.pt 
Hugo Oliveira, Jorge Bonito | ASEAN Journal of Community Engagement | Volume 4, Number 1, 2020

In 1991, the European Commission, the Regional Committee for Europe of the World Health Organization, and the European Council joined forces to launch an innovative project combining education and health promotion in order to realize the potential of both. The result was the European Network of Health Promoting Schools (ENHPS) (WHO - World Health Organization, 2020), which promoted the establishment of Schools for Health in Europe (SHE, 2020). Portugal joined ENHPS in 1994 (SNS - Serviço Nacional de Saúde, 2020). In 1998, the Portuguese Ministry of Education and the Ministry of Health formalized their commitment to foster the sustained development and enlargement of the National Network of Health Promoting Schools. The Health Promotion and Education Support Program (DGE-Direção-Geral da Educação, 2014) was approved in 2014. After three years, as a result of a partnership between the Directorate-General for Education (DGE), the Directorate-General for Health, and the Service for Intervention in Addictive Behaviors and Dependencies, the Health Education Framework was published. It focused on the following areas: $a$ ) mental health and violence prevention; $b$ ) food education and physical activity; c) addictive behaviors and dependencies; d) affection and sexuality education (DGE-Direção-Geral da Educação, 2017).

Health Education Projects (HEP) must reference the construction of a health promoting school. In this regard, Fernandes (2006) describes that these schools:

\begin{abstract}
must have a comprehensive view of health, they must see it as an integral part of the school and, therefore, they must put together education and health professionals in order to create a healthy space, where the collective and individual well-being are respected and where projects and activities contribute to the development of health and education, creating multiple opportunities for the participation of its members. The student's participation in defining the organization of the school, as well as in the design, implementation, and evaluation of activities, should be a current practice. (Fernandes, 2006, p. 6)
\end{abstract}

The HEP genesis process must also involve the construction or adaptation of an evaluation system that recognizes the degree of achievement of all its objectives so that adaptations to its functioning are applied when necessary. Internal evaluation is fundamental in that:

planning pertinent and effective interventions in the context of Health Education in the school environment involves designing and implementing assessment procedures that translate not only into a balance of the developed action, but also become a collective process of continuous learning and the search for a qualitative optimization interventions (Dias, Loureiro \& Loureiro, 2010, p. 691). 
Hugo Oliveira, Jorge Bonito | ASEAN Journal of Community Engagement | Volume 4, Number 1, 2020

The Health Promotion and Education Support Program (DGE-Direção-Geral da Educação, 2014) defined the evaluation as using descriptive and correlative methods and being centered on organic units. DGE is responsible for supervising projects developed in schools and continual monitoring and evaluation of the program. Evaluations are carried out ex-ante, based on content analysis of the application form, ongoing and ex-post, with defined indicators and goals. In this process, pedagogical supervision is a means of optimizing actions and projects developed within the educational community to streamline the construction and appearance of a "reflective school" (Alarcão, 2009) in order to learn its mission, beginning with how it is structured.

HE's purpose as an educational project provides adequate space for a good climate that promotes the development of the teaching and learning process, because "Any school regardless of its academic results, socioeconomic location, physical characteristics, can be effective, as long as a union is created between its members, which is the role of supervision" (Bernardino, 2009).

The perception that educational actors have of their role and the effects of HEP substantially influences the way they modify their individual behaviors, adopt healthy life practices, and collectively increase the level of community health based on the transformation process recommended by HE (Fennessy, 1998; Adamson et al., 2006; Leite et al., 2015; Poudel, 2018).

Therefore, the study aimed to identify the effects of the execution of HEP in clusters of schools and ungrouped schools, as perceived by teachers and students. By understanding the educational agents' perceptions about HEP, it is possible to construct an intervention framework for their optimization.

\section{Methods}

To achieve the most realistic answer to the original question, we opted for a methodological approach that would allow an access to the phenomenon from the inside by in-depth study of particular cases. A multicase comparison (Bogdan \& Biklen, 1994) centered on a narrative (Bassey, 2002) allowing discovery of divergences and common points between cases was performed. The underlying logic was that one could then predict similar results (literal replication) from case to case, or that contrasting results could be produced with predictable reasoning (theoretical replication). 
Hugo Oliveira, Jorge Bonito | ASEAN Journal of Community Engagement | Volume 4, Number 1, 2020

The study was developed in the municipality of Castelo Branco, the third largest in the country in the statistical sub-region of Beira Interior Sul, in the center region of Portugal, in the academic year 2011-2012. At the time of the study, the municipality had four school clusters and four nongrouped schools.

The sampling intentionally observed common characteristics in a heterogeneous group and analyzed by the same investigator (Bustamante, 2011). The criterion for selecting the participating educational establishments was based on their having classes in the third cycle of basic and / or secondary education.

A HEP coordinator and a student from each educational institution participated in this investigation. All the coordinating teachers interviewed were female (Nct $=5$ ), aged $42-$ 49 years. The interviewed students $(\mathrm{Nis}=5$ ) were between 12 and 18 years old (three female and two male). The structural documents for each group and nongrouped school were also analyzed (Nsd $=5)$.

This study opted to use the instrument developed by Dias, Loureiro and Loureiro (Dias, Loureiro \& Loureiro, 2013), which allows us to analyze the dynamics of implementing the HEP in order to characterize reference practices and provide recommendations to encourage adoption. The instrument allows project evaluation according to a supervisory view and well-defined criteria in five core dimensions: $a$ ) Organizational dimension; $b$ ) Community dimension; c) Ecological dimension; d) Psychosocial dimension; and e) Curricular dimension. Each dimension has defined sub-dimensions, criteria, and indicators. The quality criteria of the evaluated object are coherence, pertinence, efficiency, effectiveness, participation, and satisfaction (Dias, Loureiro \& Loureiro, 2010). The interview guide was validated by performing a preinterview at a school that was not part of the sample.

The information collection took place in two distinct stages. In the first phase, the HEP and the annual activity plans of school clusters and nongrouped schools were analyzed. In the second phase, HEP coordinators and students were interviewed. The information was recorded in audio format. The transcription was performed ipsis verbis, followed by the collection of units of meaning. Each transcript was validated by the respective interviewee.

The interviews were submitted to a content analysis process using webQDA software according to the analysis categories of the research instrument. This analysis was 
Hugo Oliveira, Jorge Bonito | ASEAN Journal of Community Engagement | Volume 4, Number 1, 2020

triangulated with that derived from the HEP and annual activity plan analysis. Three guiding questions were defined: $Q 1$ - What is the relevance and meaning attributed by students and coordinators to each HEP within their educational community? Q2 - What improvements can be made to the HEP annual activity plan according to the adopted evaluation referent? and Q3 - What kind of transformations can be introduced to improve the action of the HEP in each cluster of schools / nongrouped schools?

The information is stored in computer support and is in the custody of this study's first author. To guarantee the confidentiality of the institutions' identities, their HEP are designated by the letters A to E. Also, in order to protect the identities and opinions of the intervening subjects, the coordinators are coded from Coord. A to Coord. E, and the students are coded from St. A to St. E.

\section{Result and Discussion}

\subsection{Needs, relevance, and meaning of the Health Promotion}

We now know that attitudes are more easily generated and modified during childhood. This means there is a greater probability of success in the implementation of the HE if it is carried out in an integrated and coherent way from an early age (childhood stage). HEPs developed in the school environment are therefore of crucial importance for the entire educational community.

The genesis of a HEP also requires the construction of an evaluation system that allows the recognition of the degree of achievement of all its objectives so that adaptation to its functionality are applied when necessary. The evaluation of HEP is therefore fundamental to the optimization of their actions:

Planning pertinent and effective interventions in the context of Health Education in the school environment involves designing and implementing assessment procedures that translate not only into a balance of the action taken, but also become a collective process of continuous learning and in the search for a qualitative optimization of the interventions (Dias et al., 2010, p. 691).

The present study was developed to present a valid contribution to the optimization of HEPs for both nongrouped schools and school clusters according to and as appropriate for the educational communities' interests and needs.

After analyzing the collected information in this investigation, it became possible to elaborate on a set of suggestions allowing the different HEPs in the study to act more 
efficiently within each dimension under analysis. Here, we identify the most significant suggestions in each dimension of the different case studies: Organizational Dimension: Prepare a budget to support the HEP (HEP A - HEP E). Communitarian dimension: Determine the degree of involvement and concordance with the educational communitarian in the face of the HEP action (HEP A, HEP B, HEP C, HEP E). Ecological Dimension: Reinforce investment in peer education and identification of peer leaders within the scope of HE (HEP A, HEP B, HEP C, HEP D, HEP E). Psychosocial dimension: Determine the degree of involvement and the cooperation types in the different elements of the educational communitarian within the scope of HEP (HEP A, HEP B, HEP C, HEP D, HEP E). Curricular Dimension: Develop an adequate and individual assessment methodology for each type of activity, enabling the achievement of the degree of concordance using the performed interventions (HEP B, HEP C, HEP D).

The following results highlight the relevance and meaning students and coordinators attributed to each HEP within their educational community (Q1):

\section{HEP A}

In this project, the partners, such as the local hospital, and the actions carried out on a voluntary basis are two of the most relevant aspects of the HEP, with an emphasis on the development and acquisition of healthy habits in food and physical activity. These results align with those demonstrated by other authors, reporting that the main role in the dissemination of health promotion focuses more on university and health institutions and less on schools (Jiménez-Torres, Guerrero-Ramos \& López-Sánchez, 2013). Coord. A show us evidence of the preponderance of partners in HEP A:

\footnotetext{
We have been purchasing some material ... for example, scales, blood pressure meters. All of this was bought. Then we managed to arrange who gave us blood glucose meters, and other parameters like triglycerides and cholesterol. But then, the strips are very expensive, expire and, at this moment, are in standby. Now, with the nurses there once a week, it may be that there is a charitable soul who offers us strips and they start measuring the school population again, being also open to everyone ... to parents ... if they want to come and bring their grandmother, they will also be welcome to measure blood glucose. And nurses can take the opportunity to do an internship, to do what they like to do, as measuring all parameters, weight, height, and BMI, and make recommendations and referrals when there are deviant situations.
}

From the students' perspective, the HEP is important to daily learning about topics associated with sexual education and the consumption of psychoactive substances. This aligns with other authors' opinions (Cardozo, Dubini, Carballo \& González, 2019) 
Hugo Oliveira, Jorge Bonito | ASEAN Journal of Community Engagement | Volume 4, Number 1, 2020

establishing that we should recognize adolescents as subjects with full rights "by giving them a voice and a vote, by allowing them to convey their ideas and opinions; by listening to them and motivating their potential and capacities-allowing them to open up to new horizons, both personally and socially." With regard to this topic and during the interview, St. A says:

I liked the activity on alcoholism, because old alcoholics came here and they explained it well, because doctors digress, and they are more direct. I also really liked the lecture on sexuality because the facilitator made us very comfortable and it was a very interesting lecture because it addressed the aspect of relationships a lot.

\section{HEP B}

The intervention of teachers in the areas of addictive substance consumption and sex education is of special significance in HEP A. Regarding the first area, Coord. B says:

We have the perception of things that happen, because problems show up here or there. People are aware of them. Namely in terms of... after... the drugs, of the consumption of psychoactive substances, the... this here... there are some groups here... that make things sometimes still effervescent and therefore we try to act as for example in... for example this year we decided to go to that workshop "Me and the Others" precisely to see if we could gain in certain groups, well, interact with them and start talking about the issues to see if they... also... notice and fall into reality, because ... our problem is the older ones entering these groups and then the little ones ... and then chasing the little ones to also enter in these ... these situations.

As for the topic of sexual education, the achieved results align with other investigations in the design and implementation of an education program for sexuality and citizenship that “improves teaching planning practices and, in turn, improves student's knowledge in sexual and reproductive health services, and to a lesser extent, human, sexual and reproductive rights" (Cortés et al., 2016). In this sense and in recognition of the parents' role in the relationship of the HEP with the community, St. B says:

Regarding the Parents' Association, from what I see, they collaborate, because my mother is part of it and yes ... I think so. I've seen. For example, my mother came to school to present a lecture on sexuality, sexually transmitted diseases, affections, and... she showed us these things and we learned a lot because we were studying these subjects in science, and also learning them in Civic Training during the second period. And if I were the mother or father of a colleague of mine, I would also participate.

According to Coord. B, the dissemination of reference practices within the educational community is a driving and motivating factor for its replication, adoption, and optimization. 
HEP C

The dynamization of this HEP allows the existence of a Student Support Office (SSO) that is always open and available to help clarify questions about any area of HE. This project places a special focus on the themes of healthy eating and sexual education, and also provides support in solving problems related to interpersonal relationships, assertiveness, and indiscipline. In their interview, St. C says:

For example, one of the fundamental parts of the HEP is that they made a cabinet available down there. It was always available with someone to answer our questions, and the students who ... let's say more problematic ... when they did something bad also went to the Executive Council and then were also directed there to have a conversation with the person who was there.

In their turn, and referring to the role of the SSO, Coord. C indicates the following:

We run the risk of not reaching all students without a doubt. This is a very likely risk, even though we opened the student's office on Thursdays. But there it is, it's not the office that will meet the students, we expect that the students will go to the office. This year it was relatively well populated. When I say relatively well populated, I mean about three visits per month, which is already great! It's great, attention.

Finally, in referring to the most focused themes of the project, Coord. C points out:

It's one of the things that I have been doing, is to work on bullying, especially in the 7th grade classes. My students have not talked to me much about bullying, because they even talk about a lot, but not about bullying. They sometimes bring different and very personal themes, and I want to believe that if there were bullying situations, they would also tell me. But as this school has many interior spaces, even though there are not many employees, we have video recording, so it is not something that concerns us very much, so if there are more or less undisciplined and / or violent acts, they are on display and in this case the school management is going to intervene, parents are called, in fact many times ... "many times" is a force of expression ... by chance this year they were here four times, I was careful to note, the elements of "Safe School." For some reason it would be. So, the management is also not closed eyes, for things inside or outside, I know that it is also not prevaricated. And when it is necessary, it is necessary. But I think this is not a big problem. (...) Sex education is transversal in the project and perhaps where more has been invested. Perhaps it has been this area where most has been invested lately. Food education has now been focused on the 12 th year, and I think these are the two most significant areas.

HEP D

HEP achieves special relevance by allowing the acquisition and decoding of information by the most economically and socially needy students, within the scope of $\mathrm{HE}$, guaranteeing the intervention of multidisciplinary teams at school; namely, nurses, psychologists, and social workers. Positive interpersonal relationships established within the educational community are also identified as a very positive aspect contributing to 
Hugo Oliveira, Jorge Bonito | ASEAN Journal of Community Engagement | Volume 4, Number 1, 2020

the success of this HEP. When asked about the most relevant aspects of the project, St. D points out the following:

In my opinion, the project is good because there are always those who do not have so much information, who come from needy families, and perhaps the education they have at home is not the best, and then at school with these lectures and with this "Health Week," they get to understand better some contents.

With regard to the context within which the HEP is developed, Coord. D says:

I highlight the growing worsening of society's problems in general due to unemployment, which is also reflected in the school's parents and their students, bringing more problems of integration and violence into the school.

When asked whether partnerships were established to plan and implement the HEP, Coord. D says: "Yes, and very profitable ones. Castelo Branco Higher School of Health Nursing, the Amato Lusitano Association. This year, also with the Youth Institute."

The results of HEP D therefore align with those demonstrated by Lázaro and Martínez (2016) when they mention that:

The contribution of Health Education for the communities, in the perspectives of training and social organization outlined, makes it a potential agent of social change, as it can stimulate, facilitate or create life-changing situations for the communities. Assuming this situation, health educators should develop the most appropriate pedagogical strategies for promoting health in the community environment, taking into account the basic principles of democratic socio-educational intervention and respecting the starting points (beliefs and values) of communities for which they are directed, collaborating with them and allowing their development to achieve precise changes in social, political, economic, and environmental conditions that favor their individual and collective well-being. (Lázaro and Martínez, 2016, p. 129)

\section{HEP E}

The relevance and meaning for HEP E derive from the motivation acquired and demonstrated by students during their activities, propelling them to search for more information posteriori. According to Coord. E, HEP made it possible to observe students acquiring more sexually responsible behaviors as well as to verify a reduction in the number of young people with smoking habits. Also, according to the interviewed student, there were some lectures whose information impacted students so significantly that they wanted to share it in other spaces and with other people, especially in the family context.

Speaking of the relevance of HEP in his school, St. E mentions the following:

There are certain lectures that are really interesting and where we participate in, and it turns out to be funny because we stay with these things, and sometimes I tell them to my mom and my mom looks back at me with a face like "I don't understand anything you're saying!" [laughs]. But I like to learn things here and talk about them at home. It's funny because we learn certain information that stays with us, it turns out to be a little piece more of culture. 
After reflecting on the impact that HEP had on his peers' daily lives, the student mentions:

Regarding my colleagues, the Health Education project manages to influence the most interested. I think that this project sometimes ends up bringing them maturity, without a doubt ... sometimes it does ... because there are certain students who do not look ... who are not aware of the risks, for example in relation to health, they do not have..., they are not aware of the risks and sometimes... there are certain students who do not grow, who do not see the interest in things, and I think this ends up helping a little bit, these activities end up helping to understand things, the meaning of things and the risks that can arise from certain attitudes that... well... that are badly taken.

In turn, referring to HEP's impact on students, Coord. E points out:

They like I said, when they build something, they... a... these students don't really like to work, we can say so [laughs], they don't really like to work maybe due to the difficulties they have in building something, but if we are going to stop and... and... and saying that what we are doing is bad, we also don't... we are not going anywhere... so... this is emanating from above, I think they must have Health Education to, to become healthy citizens, isn't it? The way we found to instill Health Education was this one ... I don't know any other. Maybe with training, maybe I will get something more... but no... I really don't know. Regarding the evidence, there are, for example, students who... well, I think they have more responsible sexual behaviors. I see this in their behavior, in relation to smoking, maybe a little less smoking at the gate. It is mainly that.

These results from HEP E align with those achieved by Cardozo et al. (2017) in their evaluation of the program "Health Promotion and Youth Participation." Between 2011 and 2013, the students of the Psychology of Adolescence chair at the Catholic University of Córdoba held 423 workshops with students of different levels in two state management schools. In these workshops, they addressed various themes suggested by these same students and other members of referred institutions: violence, discrimination, sexuality, and consumption of addictive substances. One of the major conclusions of this study was that it:

...strengthens the ability of schoolchildren to reflect on the substance consumption problem, the ability to communicate with their peers and adults about this issue and makes them aware of the need to ask for help when facing a problem.

\subsection{Improvements to be introduced in the HEP activities}

Several optimization methods were identified with regard to the improvements that could be introduced in the HEP annual activity plan (Q2). For each dimension, the most relevant in these case studies were as follows: Organizational Dimension: Identification of the instrument for information collection as the basis for inventorying the student's interest topics (HEP A, HEP B, HEP C, HEP D, HEP E); Communitarian Dimension: Properly record the HEP dissemination channels in order to guarantee their visibility and timely knowledge (HEP A, HEP B, HEP C, HEP D, HEP E); Ecological Dimension: Promote and 
Hugo Oliveira, Jorge Bonito | ASEAN Journal of Community Engagement | Volume 4, Number 1, 2020

identify the emergence of leading students who participate in the development of the project activities, while also registering the degree of involvement these students have with their peers (HEP A, HEP B, HEP E); Psychosocial Dimension: Define the degree of cooperation between students, teachers and students, teachers and partners, teachers and staff, and parents/guardians and the HEP education team (HEP A, HEP B, HEP C, HEP D, HEP E); Curricular Dimension: Assess the degree of implementation and the costs of the planned HEP activities (HEP A, HEP B, HEP C, HEP D, HEP E).

\subsection{HEP optimization transformations}

Regarding the third guiding question, the results point to the following:

\section{HEP A}

Work must be done to ensure that sex education is no longer considered taboo, and this is almost exclusively a task for the project's Natural Sciences teachers. On the other hand, efforts should also be made to improve the organization of the project's collaborating partners, allowing them to optimize their activities.

Concerning the HEP relationship with the community and focusing particularly on the case of parents and guardians, St. A mention the following:

I think that involvement could be good, especially at the level of parents who can be more alert about something and then pass it on to their children. For example, when we are only students, we may not be paying attention, and with parents, it would be different. But the parents are from "another era" ... well, but my parents are also well informed ... The parents and the association know about the projects but do not help directly. I think that not even indirectly... [laughs]. At parent meetings, the project is talked about but ... nothing is done with the parents.

In addition to improving this relationship, the HEP must also be planned to be more appealing to ensure a greater number of participants in its activities. For this last aspect to be fulfilled, it is necessary that the project's educational team have more time, which has been insufficient so far.

Regarding the constitution of these multidisciplinary teams, Aliaga et al. (2016) considers:

so that there is the possibility of creating these teams, a minimum hourly availability is necessary, at least for the people who carry out the coordination. Therefore, each school center and each health center, should favor in its schedule the professionals involved in this task so that there is a real commitment to the objectives proposed by a health promoting school, avoiding the voluntarism and improvisation that, although they may provide the 
performance of healthy activities, implies the risk of lack of continuity of the project, causing sometimes the opposite effect to the proposed objectives. (Aliaga et al., 2016, p. 56)

In turn, and when invited to reflect on the biggest difficulties identified so far in carrying out the HEP, Coord. A replied:

The biggest difficulties... is Sex Education... stop being taboo in the minds of teachers.... Some, of course! And do not think that this is the task of only the poor science teachers. Because it's like this: sometimes I no longer feel like raining in the wet. I no longer feel like saying that this is transversal. It concerns everyone: inventing grids or stop inventing grids. It goes like this: if people don't feel like doing it, they don't do it. Or they do it just show that something has been done. And... and that's it... and I don't feel like saying more because otherwise I'd be also 'shooting myself in the feet', because maybe I should also perform a closer supervision, that I don't feel like! I don't even want to ... because ... well... that's how it is, this year I still didn't feel like thinking about it very seriously. I've had more to do but it is one of our intentions, as a team, for the year to start differently and I don't say how! [laughs] But it's already thought out! Not the whole team knows ... but part of the team already knows. We are going to start working on a new methodology called "Dragon Dreaming" [laughs]. That is something very much ahead, which consists of dreaming, planning, realization and celebration. And the dreams are here! (...) it's like the police ... but maybe it's the only way to take it seriously ... Because every year it's always the same conversation. Every year there are people to refile and they are always the same... because they don't want to, because they are not specialists, because they don't want to know, because that doesn't concern them very much, and then it's the same story and the transversality is lost.

Finally, we can see that in HEP A an effort must be made to attract more partners because the current allocated project resources are quite limited. In this sense:

If the availability of these human resources is indispensable, it is also necessary to have minimal economic resources that empower the project. In this way, it avoids being an economic burden for schools, which in the current situations may consider the project's survival unfeasible. These economic resources must be determined from the Ministries of Education and Health, with the commitment and monitoring of the projects (Aliaga et al., 2016).

\section{HEP B}

This HEP can improve your ability to disseminate references in order to mobilize a greater number of the student population. On the other hand, it must also establish the promotion of genuine peer education with regard to the diagnosis of health-related problems. Not a determinant, but another aspect that can be changed is to increase the number of meetings scheduled by the project's educational team, thus contributing to a better organization of activities carried out in this area. The difficulties that teachers have in concretizing HEP are pointed out by Coord. B in their highlighting the following:

It's my good will and my "pedaling" that makes this move. For now, we also have difficulty in having moments for the team to meet. It's complicated and it really has to do with our good will, as in everything at school, isn't it? Sometimes it's difficult to sensitize some colleagues to some things that we have to do, and that we think are relevant, but that they think are not 
Hugo Oliveira, Jorge Bonito | ASEAN Journal of Community Engagement | Volume 4, Number 1, 2020

important at all (...) to mobilize older students for what we would like to do such as peer education, which is the most important thing. It's involving them in these issues so that they could set an example for themselves. And this is not happening! So, these are the difficulties that we have. This is more difficult to achieve because we try to involve the Students' Association, but the Students' Association is more concerned with organizing a futsal game and a finalists' trip than Health Education itself. Okay..., I think this says everything.

Regarding the importance of planning HEP structures, processes, and the allocation of resources (Díez et al., 2016) report that:

Establishing a local plan that includes health in a transversal way, with well-being planning processes and mechanisms, is not enough; it is important to include the focus on results and evidence. Planning with a common work framework helps to overcome bureaucracy, competitiveness and the misunderstandings that will inevitably arise. The activities include establishing baselines, goals and indicators; agreements on objectives and deadlines; the development of information systems that facilitate the exchange of data and shared information, the appropriation between the actors, and the feedback, monitoring and dissemination of learning and results. (Díez et al., 2016, p. 77)

Finally, in relation to the project in question, ways to increase the degree of involvement and participation by the student association should be sought out, and they should trigger the onset of continuous efforts to captivate the target audience for the various activities, especially lectures. About the knowledge of the HEP action plan, St. B comments that:

We get to know it as the activities come up, and we don't do these activities every month. As they arise, the poster is put up on the pavilion, they come [the students] and then they will know this will happen. Because before the activity is organized and the poster is put up, nobody knows, unless the teacher says.

Coord. B comments on the advantage of having students participate in the design and implementation of the project:

One of my motivations was that one... was that they were the ones to build it. There would be immense advantages because they have a view of things different than ours. This is my Achilles' heel, I have not yet managed to make it happen.

Reflecting on the advantages of increasing the degree of student involvement and participation in HEP, as well as that of the entire educational community, Díez et al. (2016) establishes that:

The active participation of the population in community planning and program development is another necessary aspect to address local inequalities. The participation of groups interested in decisions formally includes nongovernmental actors. Community empowerment requires that citizens participate with technical teams in the design of interventions (coproduction), and assume power and control for decision-making in policies, services, and programs. (Díez et al., 2016, p. 77) 


\section{HEP C}

For a higher rate of project success, the need for more training on HE themes was diagnosed, with a special focus on assertiveness and interpersonal relationships. More attention is needed on the needs diagnosis process to ensure the designed activities are as appropriate as possible. St. C focuses on the need to create more practical activities and establish closer relationships between the school psychologist and the students:

What would I change in the project? ... Uh ... I don't know ... What would I change in the project... Maybe having a more practical activity, let's say, but I'm not seeing how... maybe a more practical activity related to bullying, would... be productive, but I'm also not seeing how... maybe if there was a closer relationship between the psychologist and the school, and the classes themselves. Because in general the office is open and ... it's there. It would be easier if the students knew. If they knew the person himself, if the person went to the classes, to talk, to be there, for example in the year nine, if you talked more with them about what they wanted to follow, like vocational guidance, and it was something we lacked, but it doesn't have to do directly with health, it was those psychometric tests to see what we... would have better... to see where we would be more successful.

González and del Pozo (2017) teach that in order to develop an accurate diagnosis, it is necessary to start from the interactions between educators and students, with a view to establishing a well-adjusted plan to match the diagnosed needs:

With all this, HE supposes a necessary interaction in which there are involved the human behaviors and the actions of the involved educators and students, in a process of ongoing formation that implies interacting to learn the meanings; as it represents the best strategy for users to receive care based and focused on their lifestyle and not on their health problems. (González and del Pozo, 2017, p. 217)

Another challenge of the project is to attract partnerships in order to increase both the amount of available resources and the range of possible activities. In addition, the project should prioritize the creation of a motivated educational team dedicated to its dynamization. Concerning the greatest difficulties experienced by teachers in promoting the HEP, Coord. C states the following:

The greatest difficulties have been designing activities and proposing partners for these activities. Diagnose, with some objectivity or with more objectivity, the first needs of the school, even though they are not far from what has already been done, from the various works that have already been done in identifying priorities in this area of health, and that we realize that they are the social problems that appear more... in terms of health... psychological, social, and physical health. What we see in society is what we have to attack. A... although each in his context may see more problems in this or that scope. But I would like to see more people, because in the end not everyone can be ... in love ... more inclined, more dedicated, or consider this to be an area of greater interest, I would like to meet people whose area of interest was health, to throw ourselves with a lot of will, without concerns about time. And I would like the school not to be so bureaucratic, it is very bureaucratic ... it makes things uninteresting ... it makes things uninteresting. 
Hugo Oliveira, Jorge Bonito | ASEAN Journal of Community Engagement | Volume 4, Number 1, 2020

The HEP team should therefore ensure that more disciplines are involved in HE processes. Finally, efforts must be made to reduce the bureaucracy of procedures, streamline the project, and make it more attractive. For this purpose, González and del Pozo (2017) propose using the instruments of Sociocultural Animation, an area born from Social Pedagogy which constitutes an excellent resource to "avoid or overcome resignation and promote a mechanism of personal and community overcoming crisis situations, lack of resources or social and cultural vitality." Regarding the relevance of this intervention, the authors discuss:

This is the fundamental element of any form of education, as it allows the social adjustment of the individual, and the need for dynamization, communitarian participation, cultural and social democracy of the individual in and from his multicultural community, which makes it necessary to foster the training of health professionals with high social relevance, which is strongly reflected in the quality of life of the population groups they serve. (González and del Pozo, 2017, p. 219)

\section{HEP D}

Due to society's worsening problems caused by high unemployment rates, which brought more integration and violence problems into the school, it is important that HEP can guarantee the intervention of multidisciplinary teams. These include psychologists, social workers and other health professionals who are capable of relieving the role of class directors. It is advantageous for the project to attract attention from younger students as well in an attempt to help them bypass harmful habits sometimes developed in the family environment. Al. D confirms the great inconsistency between the information conveyed by the HEP and the behaviors of some teachers and students, particularly regarding tobacco consumption:

In other areas, teachers try to meet our needs, but for example, in relation to tobacco, they
promote posters at the school "Tobacco kills!" "Tobacco does this... tobacco does that..." and
we pass in the hall and "Ah! How interesting!" and then we come outdoors and see a lot of
people smoking ... teachers and students. And I think the message does not get through. It gets
through on the moment we see it, and then when we got outside and "I don't want to know
what I read! What I care about is smoking."

Although a large amount of information is available in HE, it is difficult to capture the target audience's attention because many people seem uninterested in learning more about shaping their behavior according to this paradigm, as was verified in the first HE projects promoted by the Health Education Association (ADEPS), described here by Díaz (2014): 
The first Health Education projects and programs promoted by the organization emphasized the importance of health information, with a large disclosure component. Communication was not part of the initial stages of the projects, as it was limited to later disclosure, and was assigned to the spokespersons for the projects, who in general were health professionals. These experiences allowed us to see that quality information is a necessary condition to increase the population's knowledge about health issues and establish the basis for changes in conduct, but it is not enough to guarantee these changes. (Díaz, 2014, p. 8)

Therefore, after the creation of the Health Education Foundation (FUNDADEPS), and as described by Díaz, ${ }^{23}$ the approach to the language used in HE starts to be different, considering different audiences and their varying social contexts:

In a second stage, FUNDADEPS promoted an integral and integrative perspective of communication, which crosswise cuts across all its programs and actions. Now, from the moment a project starts to be designed, communication is integrated as a constitutive dimension, both in the formation of the multidisciplinary team that promotes it as in the search for building relationships with different audiences. This perspective aims to facilitate relations with the different health agents who intervene in health processes, taking into account the different target audiences and the need to adapt actions to different social scenarios.

According to Coord. D's opinion, the educational community's perception about HEP actions is that:

For some parents, namely proponents or stakeholders, the project is quite valid. For others, despite being informed, even, of the existence of an office, and of all the annual planning / dynamization per class, they continue to "ignore" the various activities.

For all these reasons, it is up to HEP to find new and more suitable ways of communicating and decoding the available information.

\section{HEP E}

In order to improve its actions' effects, the project must create conditions for adequate dynamization of the SSO by ensuring the collaboration of a health professional in the project, such as a doctor, nurse or clinical psychologist. The greatest difficulties identified so far in the implementation of the HEP relate specifically to the creation of this office, as Coord. D mentions:

The major difficulties are related to the SSO, so at this time, I can support students in the office. But it is difficult because, for example, in the areas of health, a nurse or a doctor, or a psychologist should also be present to support students. That's what we haven't yet achieved. We cannot do it. Perhaps for the next year we'll try to talk more with the nurse [name] in order to make this possible since the school is already integrated in the project "Well growing, Bad growing." Maybe we can do it... this has been the biggest difficulty, I've already tried there at the health center. Nothing was achieved. Nobody came here. Now with the project, this year, it's in a transitory phase, we have only managed a few training actions. For the next year, it 
Hugo Oliveira, Jorge Bonito | ASEAN Journal of Community Engagement | Volume 4, Number 1, 2020

will begin to exist a greater dynamization, perhaps then it will be possible to have more support at the office level.

In addition, one mission that should not be overlooked is the search for strategies to combat food shortages due to difficulties of an economic nature. The HEP must ensure that all members of the educational community have access to enough food at all times, enabling them to live active and healthy lives, as established by the Rome Declaration on World Food Security and the World Food Summit Plan of Action, which Portugal signed in 1996 (FAO, 1996). Nevertheless, access to food is not enough to guarantee nutritional security, as shown by Becerra et al. (2017) in their focus on the problem of hidden hunger.

Another measure is to guarantee the dynamization of training actions to overcome the difficulties some teachers experience in the treatment of specific themes. The project should also define strategies to make the scope of its activities more dynamic and captivating; namely, to provide more practical activities in order to ensure greater student collaboration by better capturing their attention to the importance of the addressed topics. Finally, the most frequent way to promote health at school, according to St. D, seems to be:

Through lectures ... well ... it is a means of communication, it's a way of obtaining information, but I think there should be more activities. I think that the field trips also end up enriching this a lot... I think that they help a lot through their form of communication, and sometimes through motivation because the field trips and activities of a more practical nature end up to motivate more, mainly the students to... to participate, to inform themselves and to want to know more about things, to be more aware of the themes, without a doubt.

As Bonito (2015) and Tanoto, Khoe, \& Werdahni (2019) teach us, political discourse must be based on evidence and aligned with the legal framework. HE is undoubtedly good for health and education. Higher quality HEPs improve our students' health status, increasing their academic performance and providing opportunities for greater rewards in their future quality of life.

\section{Conclusions}

In general, regarding the first guiding question Q1 - What is the relevance and meaning attributed by students and coordinators to each HEP within their educational community? Students and teachers both consider the partners of the educational community and the voluntary actions as two of the most relevant aspects of HEP, with 
emphasis on the acquisition of healthy habits. They also recognize that the practical work carried out in the areas of Consumption of Psychoactive Substances and Sex Education have special significance. In their view, HEP allows the existence of an SSO that is always open and available to help clarify existing doubts regarding any area of HE. They also recognize that the project assumes special relevance by allowing the acquisition and decoding of information within the scope of HE by the most economically and socially needy students. That is, the relevance and meaning of HEP is derived directly from the students' motivation acquired and demonstrated during its activities, compelling them to search for more information a posteriori.

As for Q2 - What improvements can be made to the HEP annual activity plan, according to the adopted evaluation referent? The interviewees indicate that it would be positive to identify the information-gathering instrument used to inventory the topics of interest to students. They also recommend properly recording the means of disseminating HEP in order to guarantee visibility and timely knowledge, as well as promoting and identifying the participation of student leaders in the development of project activities so as to record the degree of involvement of these students with their peers. It is also important to define the degree of cooperation between students; teachers and students; teachers and partners; teachers and staff; parents / guardians and the HEP education team, and finally, to assess the degree of completion and costs of scheduled HEP activities.

Regarding the last guiding question Q3 - What kind of transformations can be introduced to improve the HEP activities within each cluster of schools / nongrouped schools? Both students and teachers understand that Sex Education should no longer be taboo and an almost exclusive task for Natural Sciences teachers. The degree of involvement with and participation of the Students Association should increase, creating conditions for the creation of a motivated and dedicated team that can dynamize the HEP. Finally, a greater intervention of multidisciplinary teams in the school should be guaranteed within the HE scopes, ensuring conditions for the appropriate dynamization of the SSO with all the agents involved. Strategies should also be developed to combat food shortages that occur due to diagnosed economic needs. 
Hugo Oliveira, Jorge Bonito | ASEAN Journal of Community Engagement | Volume 4, Number 1, 2020

\section{Author Contribution}

Hugo Oliveira expressed interest in working with Jorge Bonito, who conceived of the presented idea. The theoretical framework was developed by both. Jorge Bonito conceived the methodological design. Hugo Oliveira carried out the fieldwork (interviews) and the analysis of the information collected. All authors discussed the results and contributed to the final manuscript. Jorge Bonito supervised all work in progress and completed.

\section{Acknowledgments}

This work was accomplished with the support of the Research Center in Didactics and Technology in the Training of Trainers of the Aveiro University (UID / CED / 00194/2013) and of the professor Maria de Fátima de Jesus Simões of the Beira Interior University, Portugal.

\section{References}

Adamson, G., Mcaleavy, G., Donegan, T, \& Shevlin, M. (2006). Teachers' perceptions of health education practice in Northern Ireland: Reported differences between policy and non-policy holding schools. Health Promotion International, 21(2), 113-120. https://doi.org/10.1093/heapro/dal008

Alarcão, I. (2009). Formação e Supervisão de Professores: uma nova abrangência [Teacher Training and Supervision: a new scope]. Sísifo/Revista de Ciências da Educação, 8, 119-128.

\section{http://sisifo.ie.ulisboa.pt/index.php/sisifo/article/view/140}

Alfaro, A. C. (2017). School-based oral health promotion and intervention in AMIGA (Alfonso, Mendez, Indang, General Emilio Aguinaldo, Amadeo) Cavite. ASEAN Journal of Community Engagement, 1(2). 
Hugo Oliveira, Jorge Bonito | ASEAN Journal of Community Engagement | Volume 4, Number 1, 2020

Aliaga, P., Bueno, M., Ferrer, E., Gallego, J., Ipiens, J. R., \& Moreno, C. (2016). Las Escuelas Promotoras de Salud, un entorno para desarrollar competencias y vivir experiencias positivas para la salud: la experiencia de Aragón [The Health Promoting Schools, an environment to develop competencies and live positive experiences for health: the experience of Aragon]. In V. Gavidia (Coord.), Los ocho ámbitos de la Educación para la Salud en la Escuela (pp. 45-66). Valencia, Spain: Tirant Humanidades.

https://www.uv.es/comsal/pdf/librocomsal.pdf?_sm_au_=iVVjJjMZ0J76TNJD

Bassey, M. (2002). Case study research. In A. Briggs, M. Coleman, \& M. Morrison (Eds.), Research Methods in Educational Leadership and Management (pp. 108-121). London, England: SAGE Publishing.

Becerra, H., García, J. F., Vázquez, M. C., Alvarado, A. M., \& Romero, H. (2017). Panorama general y programas de protección de seguridad alimentaria en México [Overview and food security protection programs in Mexico]. Revista Médica Electrónica, 39, 741-749. http://www.revmedicaelectronica.sld.cu/index.php/rme/article/view/2124/pdf_28 7

Bernardino, E. A. (2009). (Re)Construção da Identidade Profissional do Professor Supervisor [(Re)Construction of the Professional Identity of the Supervising Professor] (Mastes's thesis, University of Lisboa).

https://repositorio.ul.pt/bitstream/10451/3492/1/ulfc055688_tm_Elisabete_Berna rdino.pdf

Bogdan, R. \& Biklen, S. (1994). Investigação Qualitativa em Educação: Uma Introdução à Teoria e aos Métodos. Porto, Portugal: Porto Editora.

Bonito, J. (2015). La educación para la salud en la actualidad: algunas breves notas [Helth Education today: some brief notes]. Atención primaria, 47(Espec Cong 1), 32-37. https://www.elsevier.es/es-revista-atencion-primaria-27-pdf-X0212656715474954 Burgher, M., Rasmussen, V., \& Rivett, D. (1999). The European Network of Health Promoting Schools: The alliance of education and health [internet]. Copenhagen, Denmark: International Planning Committee (IPC). 
Hugo Oliveira, Jorge Bonito | ASEAN Journal of Community Engagement | Volume 4, Number 1, 2020

Bustamante, G. (2011). Aproximación al muestreo estadístico en investigaciones científicas [Approach to statistical sampling in scientific research]. Revista de Actualización Clínica Investiga, 10(476), 478.

http://www.revistasbolivianas.org.bo/scielo.php?pid=S2304-

37682011000700006\&script=sci_arttext

Cardozo, G., Dubini, P., Carballo, M., \& González, A. S. (2019). Promoción de salud y participación juvenil. Prevención del consumo de sustancias [Health promotion and youth participation. Prevention of substance use]. Anuario Digital de Investigación Educativa, 20, 113.

http://revistas.bibdigital.uccor.edu.ar/index.php/adiv/article/view/3502/2029

Cardozo, G., Dubini, P., Carballo, M., González, A. S., Arcusin, N., Martínez, P., \& Torres, G. R. (2017). Programa de proyección social "Promoción de la salud y participación juvenil." Años 2008 al 2015 [Social projection program "Health promotion and youth participation." Years 2008 to 2015]. Debates actuales en Psicología y Sociedad, 1, 108115.

https://dialnet.unirioja.es/servlet/articulo?codigo=6221835

Cortés, D., Flórez, C. E., Ibarra, M. C., Martínez, D., \& Trujillo, E. V. (2016). Educación de la Sexualidad, prácticas docentes y conocimientos de los estudiantes: una evaluación del Programa de Educación para la Sexualidad y Construcción de Ciudadanía (PESCC) (No. 014541) [Sexuality Education, teaching practices and student knowledge: an evaluation of the Sexuality Education and Citizenship Construction Program].

https://repository.urosario.edu.co/bitstream/handle/10336/11948/dt187.pdf

DGE-Direção-Geral da Educação. (2014). Programa de Apoio à Promoção e Educação para

a Saúde [Health Promotion and Education Support Program] [internet]. Lisboa, Portugal: Direção-Geral da Educação.

https://www.dge.mec.pt/sites/default/files/Esaude/papes_doc.pdf

DGE-Direção-Geral da Educação. (2017). Referencial de Educação para a Saúde [Health Education Reference] [internet]. Lisboa, Portugal: Ministério da Educação-DireçãoGeral da Educação.

https://www.dge.mec.pt/sites/default/files/Esaude/referencial_educacao_saude_vf_ junho2017.pdf 
Dias, M., Loureiro, M., \& Loureiro, M. (2010). Avaliação de Projetos em Educação para a Saúde em meio escolar: um referencial possível [Evaluation of Health Education Projects in schools: a possible reference]. $2^{\circ}$ Congresso Internacional sobre Avaliação em Educação/Aprender ao longo da vida: Contributos, perspetivas e questionamentos do currículo e da avaliação (p. 691). Braga, Portugal: Universidade do Minho.

Dias, M., Loureiro, M. \& Loureiro, M. (2013). Projetos de educação para a Saúde em meio escolar: da avaliação às práticas de referência [School health education projects: from evaluation to reference practices]. Revista Portuguesa de Educação, 26(1), 287-306. https://doi.org/10.21814/rpe.3261

Díaz, H. A. (2014). La Comunicación en la Educación para la Salud [Communication in Health Education]. Revista española de comunicación en salud, 5(1), 8-13. http://www.aecs.es/5_1_3.pdf

Díez, E., Aviñó, D., Paredes-Carbonell, J. J., Segura, J., Suárez, Ó., Gerez, M. D., ... Camprubí, L. (2016). Una buena inversión: la promoción de la salud en las ciudades y en los barrios [A good investment: health promotion in cities and neighborhoods]. Gaceta Sanitaria, 30(1), 74-80.

https://doi.org/10.1016/j.gaceta.2016.04.015

FAO-Food and Agriculture Organization of the United Nations. (1996). PR 96/50-Accord sur Declaration de Rome et Plan d'Action [internet]. Retrieved October 19, 2019, from http://www.fao.org/WAICENT/OIS/PRESS_NE/PRESSFRE/prfr9650.HTM

Fennessy, D. (1998). Teachers' perceptions of the effects of in-service education and school based support on their teaching. Paper presented at the British Educational Research Association Annual Conference, The Queen's University of Belfast, August 27th $-30^{\text {th }}$ 1998.

\section{http://www.leeds.ac.uk/educol/documents/000000837.htm}

Fernandes, M. M. (2006) Escola Promotora de Saúde: A Participação dos Alunos nas Práticas de Prevenção do VIH/SIDA em Meio Escolar [Health Promoting School: Student Participation in School HIV / AIDS Prevention Practices] (Mastes's thesis, University of Trás-os-Montes e Alto Douro, Portugal). 
Hugo Oliveira, Jorge Bonito | ASEAN Journal of Community Engagement | Volume 4, Number 1, 2020

González, J. B. \& del Pozo Serrano, F. J. (2017). Educación para la salud con adolescentes: un enfoque desde la pedagogía social en contextos y situaciones de vulnerabilidad [Health education with adolescents: an approach from social pedagogy in contexts and situations of vulnerability]. Salud Uninorte, 33(2), 213-223.

https: //www.redalyc.org/articulo.oa?id=81753189014

Jiménez-Torres, M. G., Guerrero-Ramos, D., \& López-Sánchez, M. (2013). Publicaciones sobre educación para la salud en las instituciones educativas españolas (1993-2013) [Publications on health education in Spanish educational institutions]. Revista Iberoamericana de Psicología y Salud, 4(2), 65-79.

https://dialnet.unirioja.es/servlet/articulo?codigo=4314042

Karasimopoulou, S., Derri V., \& Zervoudaki, E. (2012). Children's perceptions about their health-related quality of life: effects of a health education-social skills program. Health Education Research, 27(5), 780-793.

https://doi.org/10.1093/her/cys089

Lázaro, A. M. S. \& Martínez, A. G. (2016). Prevención del abuso de drogas y promoción de la salud en los jóvenes [Prevention of drug abuse and health promotion in young people]. REXE-Revista de Estudios y Experiencias en Educación, 7(14), 117-130.

https: / / dialnet.unirioja.es/servlet/articulo? codigo=2938381

Leite, C., Machado, M. F., Vieira, R., Marinho, M., \& Monteiro. (2015). The school health program: teachers' perceptions. Investigación y Educación en Enfermaría, 22(2), 1-8.

https://doi.org/10.17533/udea.iee.v33n2a10

Morón J. A., Pedrero, E., \& Pérez, I. (2017). Introdución [Introduction]. In J. A. Morón, I. Pérez \& E. Pedrero (Coords.), Educación para la Salud y Prevención de Riesgos Psicosociales en Adolescentes y Jóvens (pp. 9-18). Madrid, Spain: Narcea.

Poudel, A. (2018). Teachers' Perception on School Health Services. Journal of Health Promotion, 6, 5-10.

https://doi.org/10.3126/jhp.v6i0.21779

SHE - Schools for Health in Europe. (2020). Schools for Health in Europe [internet]. https://www.schoolsforhealth.org/

SNS - Serviço Nacional de Saúde. (2020). Saúde Escolar [school health] [internet]. https://www.sns.gov.pt/sns-saude-mais/saude-escolar-2/ 
Tanoto, R., Khoe, L., \& Werdhani (2019). Mata-Data: data visualization in approaching evidence-based health policy. ASEAN Journal of Community Engagement, 3(1). https://doi.org/10.7454/ajce.v3i1.145

WHO - World Health Organization. (2020). European Network of Health Promoting Schools: the alliance of education and health [internet].

https://www.euro.who.int/en/health-topics/Life-stages/child-and-adolescenthealth/publications/Pre-2005/european-network-of-health-promoting-schools-thealliance-of-education-and-health 